Archives de sciences sociales des religions

109 | janvier-mars 2000

Formes religieuses caractéristiques de

l'ultramodernité : France, Pays-Bas, États-Unis, Japon, analyses globales

\title{
Spiritual Seeking in the United States: Report on a Panel Study
}

\section{Wade Clark Roof}

\section{QpenEdition \\ Journals}

Electronic version

URL: http://journals.openedition.org/assr/20174

DOI: 10.4000/assr.20174

ISSN: $1777-5825$

Publisher

Éditions de l'EHESS

Printed version

Date of publication: 1 March 2000

Number of pages: $49-66$

ISBN: 2-222-96690-6

ISSN: 0335-5985

\section{Electronic reference}

Wade Clark Roof, «Spiritual Seeking in the United States: Report on a Panel Study », Archives de sciences sociales des religions [Online], 109 | janvier-mars 2000, Online since 19 August 2009, connection on 30 April 2019. URL : http://journals.openedition.org/assr/20174; DOI : 10.4000/ assr.20174

This text was automatically generated on 30 April 2019.

(c) Archives de sciences sociales des religions 


\title{
Spiritual Seeking in the United States: Report on a Panel Study
}

\author{
Wade Clark Roof
}

Several years ago, media headlines broke when it was discovered that First Lady Hillary Rodham Clinton was having imaginary conversations with Eleanor Roosevelt, dead now for more than thirty years. The revelation that the First Lady was using visualization techniques and guided meditations in her imaginary conversations in the White House caught the immediate attention of various religious constituencies, who responded rather predictably: Christian fundamentalists took shots at New Agers calling them pagan and irreligious. And New Agers fired back calling the fundamentalists rigid and closedminded.

2 But what is interesting is, that reactions were short-lived and quite mild. Polls taken in the week following the news report found that few Americans actually thought the behavior of the First Lady was all that strange; public opinion of her hardly changed. Some people rushed to her defense saying that the First Lady was a committed Christian, that she had not abandoned the values and teachings of her Methodist background. Further, it was argued that the process and practice of "oul-making"using psychic Jean Houston's contemporary techniques was in no way antithetical to belief in Jesus Christ and other Christian doctrines. Prayer, it was said, as practiced by Christians historically might be thought of as a form of conversation and that monastic orders like the Jesuits had for centuries had their "piritual Exercises,"hich in the Jesuit case involves imagining one's own involvement in the Gospel story. Soulmaking could take many forms - so what was strange about what Hillary Clinton was doing? Wasn't a Methodist-even one in the White House - entitled to some latitude? There is a paradox involved, as The New York Times reporter Peter Steinfels (1996) pointed out, that while New Age practices often provoke sharp reactions, large numbers of Americans, including many conventionally religious people "nap up its books, rely on its alternative medicines and pay coaches and consultants to teach its techniques for reducing stress and focussing attention".

3 Within two weeks of the event, attention shifted from the First Lady to how rapidly such spiritual practices were becoming mainstream in the United States. Was what she was 
doing any different from "gitimate"human potential exploration? Far from being cultlike or a guru-activity, it was hailed as a type of creativity-enhancingexercise similar to that widely practiced in many sectors of the society today. Large corporations and business firms like Boeing, Lotus Development, Medtronic, and the World Bank sponsor seminars on spirituality and management techniques for their supervisors where there is talk about "soul,"'envisioning," and "getting the self and the corporation into sync with one another."In editorials of newspapers and retreat centers around the country, discussion shifted to how deep was the spiritual hunger of Americans. Best-selling New Age author James Redfield (1996: 1) suggested that the episode helped to focus attention upon "he human potential exploration itself: what indeed is this search for quality and spiritual fulfillment that is occurring everywhere?"

This episode with the First Lady points to a growing and increasingly recognized spiritual quest culture in the United States. By a quest culture, I refer to an ethos emphasizing spiritual seeking and exploration with much talk about "ourney," "rowth,"'iscovery,"and "ultivation of the interior life." vidence of this culture is widespread: words like "spirit" and "soul" are commonplace in conversations in cafes and coffee bars. "Spirituality," more so than "religion," that is, emphasis upon personal reflection and meaning rather than institutional dogma or morality, receives considerable attention on prime-time television programs. This is best illustrated by the fact that the federally-funded Public Broadcasting System in late 1995 began a well-received series of programs on the theme of "Searching for God in America." So popular was the series of interviews with major religious figures and spiritual teachers, now two years after the series was first aired, reruns continue to be played and discussed in many churches and small groups. Across the country generally, there is much curiosity about and interest in spiritual matters, both inside and outside organized religion. As sociologist William Sims Bainbridge (1997: 390) says: "The New Age phenomenon surrounds conventional religion like a cultural fog bank, almost completely lacking in large-scale formal organization but giving the fringes of faith a mysterious appearance."

This spiritual quest culture parallels a shift in popular psychology, a shift some commentators regard as a significant development in late- or post-modernity. "We are becoming fluid and many-sided," writes psychologist Robert J. Lifton (1993: 1), his point being that people feeling that their lives are fragmented today are increasingly open to revision and adaptation in their identities and outlook. "Without quite realizing it," Lifton continues, "we have been evolving a sense of self appropriate to the restlessness and flux of our time. This mode of being differs radically from that of the past, and enables us to engage in continuous exploration and personal experiment. I have named it the protean self after Proteus, the Greek sea god of many forms."

Is Lifton right? Is there a new sense of self emerging?

7 It seems not just coincidental that the metaphor of a spiritual quest takes on significance at a time when many of traditional religion's underpinnings of the culture have become more tenuous. One hears about the crisis of modernity and terms like "post-traditional", "post-dogmatic,"'post-Christian," and "post-modern" are increasingly common in lay audiences, which itself may contribute to an ethos of questing for spiritual meaning and direction. A reclaiming of the inner life and renewed stress upon the importance of inner truths surface just when passionate voices on behalf of moral relativism and multiculturalism are widely heard and proponents of "personal knowledge" as opposed to the "unity of knowledge" attract mounting attention. Much attention is given to "authentic" 
experience, to recovery from addiction, to holisticthinking. In fact, the quest theme finds widespread commercial expression in the United States: "Voyager,"'Explorer,"'Pathfinder," even "Quest" are model names on cars and trucks; "Life is a journey. Enjoy the ride," so says Nissan's commercial on television. The US Army co-opts a basic teaching of humanistic psychology when it proclaims in its commercials: "Be all you can be." Quest as a motif captures the media and popular culture.

\section{I - Features of contemporary spirituality}

The first question to ask is: what accounts for this widespread seeker culture? Very much at the center of these changes, I argue, are the post-World War II generations. The huge baby boom generation followed by Generation Xers are the major carriers of this shift in spiritual sensitivities. Obviously the culture is widely diffused throughout the society, but it is these younger cohorts that are setting the pace. Values important to them include the environment, the reclaiming of the feminine, the holistic, and quality of life - all identified by Inglehart (1990) as "post-materialist" values. Throughout much of the Western world, signs point to the rise of a generic spiritual culture, one that is no longer deeply grounded in Christianity and open to the melding of insights from a variety of religious and metaphysical traditions (see Roof, Carroll, and Roozen, 1995). But here, my comments are limited to the United States.

9 To grasp the setting for this interest in spirituality, it must be recognized that in the United States large numbers of young people born after World War II dropped out of churches, synagogues, and temples growing up in the sixties and seventies. It was a time of anti-establishment sentiment and countercultural styles when new norms of sexuality, family, and lifestyles confronted older, more conventional religious beliefs, values and practices. These developments helped to erode an older normative culture aligned with a Protestant America and ushered in a malaise that widely affected organized religion: oldline Protestant churches today suffer from aging constituencies and a conspicuous absence of young members. Roman Catholic and Jewish communities suffer to a lesser extent. Many of the young people who dropped out at the time now know very little - and their Generation X children (now in their twenties) know even less - about religious teachings except what they have picked up largely from friends, the movies and television. Many in both generations have turned to Evangelical Protestantism because of its attention to personal needs and firm moral and religious teachings; but many perhaps most - just dropped out and settled for a privatized form of religion, often with little clarity of belief or genuine commitment. The lingo found in many evangelical churches underscores the larger point about the cultural context: recruits are described as "pre-Christians" or "potential Christians." At the University of California at Santa Barbara, my students say there are four main religious groups on campus: Jews, Muslims, Catholics, and Christians! By "Christians" they mean evangelical Protestants, and for a considerable number of the students there is seemingly little awareness that Roman Catholics and Protestants share a common Christian heritage, much less an awareness of differences in beliefs and practices among the numerous Protestant denominational bodies. Boundaries that oncedistinguished one religious group from another in the mainstream culture now lack significance to many younger Americans.

Moreover, these younger generations are at the very forefront of the social and cultural dislocations that have altered the ontological meaning of religion: exposure to cultures 
and religions from around the world; the influence of a media-dominated world where film and television spin out many of the narratives by which people live; increased pluralism, not just in religion but in lifestyles and cultural values. On top of all this, these generations have grown up in a world where virtually anything can be, and often is, turned into a commodity. Capitalism has infused religion to a degree perhaps greater than ever before, creating new-style televangelists, selling God for donations, and turning religion into slogans on T-shirts and bumperstickers. And not surprisingly, a generation that experienced Vietnam and learned to question political authorities now questions religious hucksters no less and often approaches religion generally in a posture of skepticism wondering if anything authentic can be found within it.

11 Better educated than any generation ever, many young Americans belong to the so-called "knowledge class" - those who create, interpret, and disseminate information, very much a part of a computer and Internet-based technoculture. In this emerging technoculture, they approach religion less as a given reality, and more as an option. As theorists have long said, modernity creates a situation where people are forced to choose what to believe. We are made aware of competing religious symbols and practices, and as a result people often drift around in a sea of religious possibilities unsure whether any one faith is any more "true" or "credible" than any other. Moreover, in late twentieth-century, many people look upon cultural symbols -including religious symbols - as humanly constructed, and therefore, if a human creation, subject to negotiation and interpretation. This perpetuates a degree of uncertainty and relativism while at the same time encourages curiosity and quest. Paradoxically, many young Americans know more about the religions of the world than any generation ever, yet are probably the least sure of what to believe or how to find their way through the cultural and religious maze now encountered in contemporary society.

Still another factor should be considered: many in the baby boom generation are now passing through the ages of mid-to-late forties and early fifties, that is, a time of midlife transitions. If as psychologists say this is a time of soul-searching, these people are positioned to experience midlife differently than earlier generations: they have more choices, they are living longer, and they are less rooted in a stable moral and religious culture. Much of the creativity we witness at present arises out of an extended adult phase of life - what the popular writer Gail Sheehy (1995) calls "middlescence." It is a period when people frequently shift careers, go back to school and re-tool themselves, many go through a divorce and re-marry. Such events force people to ponder the meaning and purpose of their lives. Demography thus takes on some semblance of destiny: throughout the 1990s and well into the first decade of the next century, large numbers of Americans will be passing through these critical self-reflexive years.

The phrase - self-reflexive - is important. More than just a mid-life phenomenon: life generally in late twentieth-century, given all our pluralism in the form of competing worldviews, moralities and values, encourages a high level of reflection. Increasingly we are made aware not just of choices, but of the consequences of our choices. Modernity allows for greater control over life, yet also makes people more aware of the gravity of those decisions; individuals as well as institutions must assume some degree of selfmonitoring and responsibility for courses of action (Giddings, 1990). And that may be a fundamental reason why this is a time of widespread spiritual quests. Approaching the end of the twentieth-century, people are aware that it has been one of the bloodiest of centuries, remembered for wars, global environmental destruction, AIDS, and the 
Holocaust, and that increasingly, humanity holds within its own hands its destiny. Viewed in this context, spirituality becomes a search for a meaningful personal narrative amidst the erosion of grand narratives, an exercise that looks both inward and outward in hopes of finding a more holistic vision of life. "Reflexive spirituality" is a highly selfconscious effort at sustaining a spiritual basis of life drawing off the resources of the past combined with an on-going monitoring and evaluation of how that spirituality can be enriched as new challenges and needs arise.

\section{II - Empirical patterns}

In order to understand better the rise of this quest culture, beginning in 1988 I conducted a large-scale study of younger Americans and their values and beliefs. Funded by the Lilly Endowment, Inc., a private philanthropy interested in religious trends, the study involved a telephone survey of 1400 randomly selected persons born in the years from 1946 to 1962 (known as "baby boomers") and intensive telephone interviews with 536, plus face-toface, in-depth interviews with almost 100 of them. These interviews were conducted in four states providing for regional diversity: Massachusetts, California, Ohio, and North Carolina (see Roof, 1993, for methodological details). More recently, in a second round of telephone interviews in 1995-96, we spoke with 411 of the original 536 people. Data from this panel study are unique among surveys on religion in the United States and unusually rich for describing trends for a cohort often regarded as the "lead generation" setting the cultural, religious, and political mood of the nation. Here summary findings from this panel study are reported in three parts: (A)involvement in organized religion, (B)broad spiritual interests, and (C)spiritual journeys.

\section{A. Involvement in Organized Religion}

Based upon the large 1988-1989 survey conducted by a polling firm, two-thirds of those having grown up in practicing religious homes had dropped out of active participation in a church, temple, or synagogue for an extended period (two years or more). Most dropped out in the teenage years, the older ones deeply affected by the Kennedy assassination and the Vietnam War, the younger ones by Watergate and the long gas lines created by the oil embargos of the early seventies. By the time we interviewed them in the first survey, $25 \%$ of those dropping out had returned to active religious participation in some faith tradition. Growing older, getting married, and having children all contributed to their return. The religious breakdown in 1988-89was as follows: $10 \%$ nonbelongers, $90 \%$ belongers. Among belongers, $33 \%$ were loyalists, or had never dropped out of religious group; $25 \%$ of those who had dropped out were returnees; and $42 \%$ remained dropouts. Clearly, the generation was deeply fragmented in its value-commitments and religious loyalties despite a high level of religious affiliation.

But when we interviewed these same people in 1995-96, we were surprised to find very high levels of switching in and out of organized religion. Forty-six percent of those earlier who were the most committed - the loyalists - remained highly involved, but $29 \%$ said they were only occasional participants, and $25 \%$ said they hardly ever or never attended religious services (See diagram). Interestingly, among the earlier dropouts a third of them at the time of the later survey said they were now very active in a religious group. Less than a third of the returnees in 1988-89 reported now being very active in a religious 
group, and more than a third said they were hardly ever or never active. For the population we surveyed, it was clear there was little grounding as measured by institutional participation.

Trends in Religious Participation: 1988-89 to $1995-96$

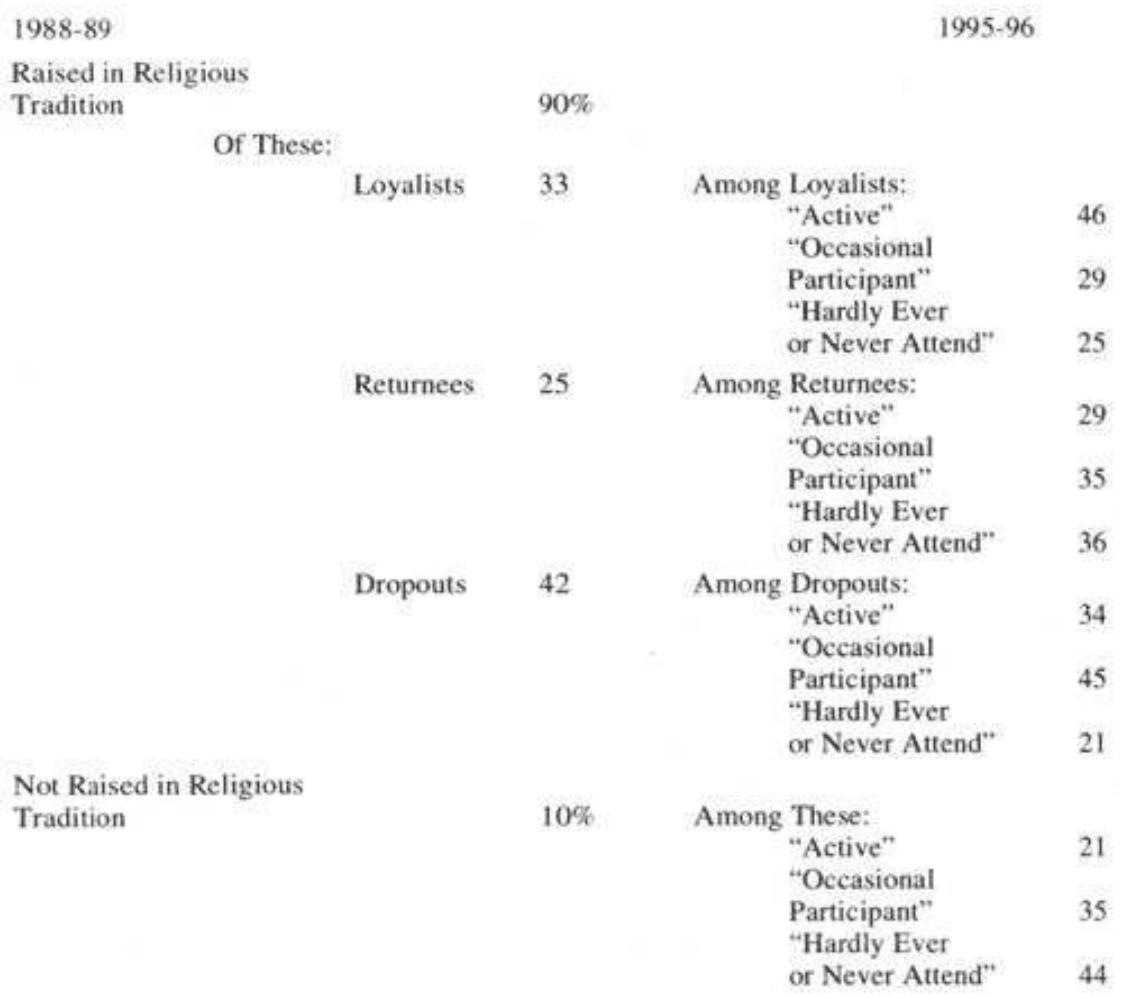

Other measures indicated considerable fluidity in their religious lives as well. Whereas $86 \%$ had once indicated they believed in God, now they sorted out in roughly three equal groups: a third as "strong believers," a third having "occasional doubts," and a third describing themselves as "seekers not always sure what to believe." Manyof the loyalists as well had become inactive. But there was the opposite pattern as well: a third of those who were dropouts in 1988-1989 now reported attending religious services weekly or more and a half indicated they were "strong believers." The picture that emerges is that of a dynamic, fluid religious population moving in and out of religious institutions, and many doing so many times at various phases in their lives. Organized religion for this cohort is an "option," and one which may be exercised frequently or infrequently depending upon the individual's own needs and preferences.

Related to the above is another important observation: for the great majority of the people we interviewed, the religious and the spiritual overlap. Asked whether they considered themselves as "religious," 73\% said yes; when asked if they were "spiritual," $71 \%$ answered positively. Yet the correlation between the two is hardly perfect indicating that there is a gap between the "religious" and the "spiritual" - perhaps a growing gap. But this does not necessarily translate into a simple break between ecclesiastical institution and personal, or privatized spirituality. In the United States religious faith and practice are highly privatized to begin with, which means that the current interest in spirituality finds expression in religious as well as non-religious settings. Actually, the data show the patterns to be quite complex: $59 \%$ of the respondents claim to be both 
religious and spiritual; $15 \%$ say they are religious but not spiritual; $14 \%$ report being spiritual but not religious; and $12 \%$ claim they are neither religious nor spiritual. So complex a pattern makes for a rich, multi-layered religious and spiritual landscape. While atheism itself does not flourish in the American context, agnosticism and uncertainty of belief are fairly common; there is disengagement from institution and external authority, but also a great deal of inward searching and spiritual exploration, both inside and outside of organized religion. It is a situation that does not permit easy generalizations about the relation of individuals to institutions.

\section{B. Broad Spiritual Interests}

In the first survey, we developed a battery of items to determine the breadth of spiritual concerns of the post-war cohort. One concern that became obvious early on was the seriousness of exploration, or interest in "checking out" new teachings and philosophies. No one religious or spiritual tradition has all the answers, so people told us, and hence one should look for truth wherever one can find it. Thus we asked in the survey: "Is it good to explore many differing religious teachings and learn from them, or should one stick to a particular faith?" Sixty percent of the respondents said they preferred to explore, $28 \%$ said stick to a faith, and $11 \%$ could not choose or said do both. Even the majority of born-again Christians (51\%) chose to explore, as compared to $66 \%$ of all others. Among born-again Christians, explorations are more grounded in traditional faith, but they too have been deeply touched by the quest spirit of the time.

Another indication of the quest involves looking inward as opposed to shared worship experiences. We asked: "For you, which is most important: to be alone and to meditate, or to worship with others?" Admittedly something of a false choice since people may opt for both, the question was aimed at tapping the extreme responses for a generation often described as highly individualistic and introverted in their approach to the sacred. Half of the respondents answered saying they preferred to be alone, plusanother $18 \%$ said both were important (or they were unable to choose between them), which means that twothirds favored a religious style emphasizing meditation and/or aloneness. With bornagain Christians, there were significant numbers opting for aloneness and meditation as well: $41 \%$ as compared to $57 \%$ of all others. Americans generally are individualistic in their religious views, though likely the inward turn toward a more personal spirituality is more pronounced for this generation.

21 A third item tapped religious universalism, or belief that you can learn from other religions. We asked for agree or disagree responses to the statement: "All the religions of the world are equally true and good." The population was split down the middle: $48 \%$ opting for the relativistic approach, $47 \%$ disagreeing, and $5 \%$ unable to decide. That is a significant, and somewhat surprising finding, pointing to a deep split in the country's religious life and the fact that large numbers of young Americans look upon religions in the plural and largely as symbolic resources, but with no single tradition as necessarily having a monopoly on truth-claims. As might be expected, fewer born-again Christians opted for the relativistic approach: $28 \%$ as compared to $63 \%$ of all others. But the very fact that more than a fourth of them hold to a radical relativistic view toward all religions indicates just how far the norms of religious relativism have penetrated. spiritually bankrupt. According to the survey, $54 \%$ agreed "that churches and synagogues 
have lost the real spiritual part of religion." Not too surprisingly, more evangelical Christians (58\%) agreed with the statement than did others. Many of the evangelicals agreeing with the item belong to "seeker churches," non-denominational churches, or house churches, all of which tend to regard themselves as different from the more established religious bodies. Another question, far more radical, asked if respondents agreed with the statement "People have God within them, so churches aren't really necessary." This borders on being an anti-American statement, yet $31 \%$ of all respondents actually agreed with it. Thirteen percent of born-again Christians agreed! It is unclear whether agreement is mainly with the notion that "God is within" or that "churches aren't necessary," but the two combined makes for a strong statement for Americans to endorse. Lacking historical data it is hard to know how this differs from previous times, but the fact that almost one-third of the boomer population agrees with the statement reveals just how deep the anti-establishment currents run.

Finally, we asked about why people were involved in religious organizations. From a traditional point of view, the reason should be rather obvious: if people are committed to the faith and have convictions, they usually feel some sense of duty and obligation to participate and to support the organization. Americans have generally felt this way, which accounts for the relatively high churchgoing and church membership patterns for the country as a whole. But does this hold for a generation so greatly influenced by a consumer culture placing emphasis upon the personal rewards that go with religious attachment? Hence we asked our respondents: "Which of the following best expresses your view? Going to church/synagogue is a duty and an obligation, or going to church/ synagogue is something you do if you feel it meets your needs." Three-fourths (76\%) chose the latter, emphasizing the psychological benefits that are held up as important to those who are actively involved in churches and synagogues. Two-thirds of born-again Christians indicated this same reason for going to church -powerful evidence of a widespread psychoculture in religious America.

In sum, the findings in 1988-89 were rather conclusive: large sectors of the American young adult population, including born-again evangelicals and charisma-tics, expressed deep spiritual concerns. Spirituality was not something bubbling up from the margins of the society; it claimed the attention of mainstream constituencies in all regions of the country. It was expressed in various ways - as searching, exploring religious teachings, spiritual growth, stress upon inner realities, meeting one's own needs. While those interested tend to be somewhat more educated and middle-class, the messages in the interviews were much the same: Americans were hungry for greater spiritual depth and were looking to meet this need by examining a variety of religious and metaphysical beliefs and practices. Spirituality and psychology often fused creating a highly subjective mode of discourse.

Our 1995-1996 survey revealed similar findings except that the respondents were somewhat more involved in religious communities, be they congregations, house churches, or small groups of one kind or another. Prayer and Bible study groups, recovery groups, and spiritual support groups drew the interest of respondents more than in 1988-89. Though people were more anchored in communities, belief in reincarnation, in psychic powers, and in the importance of thinking for one's self in religious matters remained roughly the same. The evidence would suggest that no matter how involved the younger generations are in religious groups, they bring with them a subjective and highly protean religious style, and one not easily contained by institutional or doctrinal 
boundaries. Put differently, the post-war generations now having grown older are less overtly anti-institutional, but no less insistent on deciding for themselves what beliefs to hold and what groups to join.

\section{Spiritual Journeys}

For many young Americans, spirituality is thought of as a process, as movement, as journey. But there are at least three major patterns, or styles of spiritual journeys, each with its own trajectory and distinctive motifs. Considering that the great majority of Americans, including the baby boom generation, identify with some faith or denominational tradition, spiritual journeys almost inevitably touch upon organized religion one way or another. As we have already observed, there is considerable movement in and out of the churches, synagogues, and temples - which means that spiritual journeys can be complex ventures, often self-authored in a way that is deliberate and planned yet also shaped by random events and experiences. If there is a cardinal tenet Americans hold about religion, it is that they should work it out for themselves in keeping with their preferences and needs. This does not usually mean outright rejection of organized religion so much as the affirmation that individuals should decide whether, where, when, and how they will relate to a church or religious group. For the post-war generations especially, this choice rests on one fundamental consideration - whether such involvement helps them to "grow" spiritually.

One type of spiritual journey takes previously non-religious or nominally religious people back to faith. This is not a large movement, numerically, but even so an important one: Roman Catholics reclaiming a religious faith, or switching to the Episcopal Church, especially following a divorce; mainline Protestants rediscovering their own theological heritage; women often finding female role-models in the Bible and in religious traditions; various people coming to understand that helping others isa meaningful complement to their own more self-centered searching. Most people on this spiritual trajectory say they are both "spiritual" and "religious." It might be said that for these people the religious contains the spiritual - that is, they find in religious symbol and narrative a meaningful self-identity. To a considerable degree, the success of this journey depends upon whether or not a seeker finds a particular congregation, a house church, or some kind of religious activity that meets a felt need; the chemistry between seeker and group is crucial. A phrase baby boomers use in describing why or why not they affiliate with a religious group is whether they "feel comfortable" -which means if they feel accepted no matter what the dress or lifestyle, if they can ask "hard" questions and not be rejected, if they can find an environment supportive of spiritual searching. Typically, these seekers are older, often they have tried out other spiritual alternatives and have simply grown tired of the search. Many have pursued their own narcissistic self-fulfillment and have finally decided the pursuit to be a dead-end search if concerned only with themselves; increasingly they give more attention to family, to sharing experiences, and to worthy causes.

28 A second type of spiritual journey, numerically more prevalent than the first, is that found among many evangelical Christians. Here the journey is defined as growth in faith, "walking the walk" as many of them say. Practices like reading the Bible, prayer, devotional activities, and reading inspirational books are regarded as conducive to personal growth. Evangelicals, like non-evangelicals, move from church to church until 
they find a congregation that caters to their liking, to their unresolved questions, to their own mode of seeking. "Recovery" and "journey" are popular cultural motifs around which these people often relate: many are overcoming addictions or prior abuse, and wanting to set new goals for their lives; they adopt a view of life as a process of continuous growth and learning. Growing numbers of evangelicals speak of being "spiritual" as well as "religious"; seldom is there strong hostility toward the latter term. Studies show that what these seekers want most is not necessarily otherworldly beliefs or strict morality, often associated with fundamentalist churches, but rather programs that address personal needs and inspire them to commit their lives to God. Many evangelical seekers like the atmosphere found in the so-called "seeker churches", especially tolerance for differences, openness toward divorced people, use of popular music, and the concession that no one church has a monopoly on truth (Shibley, 1996; Miller, 1997). These "New Evangelicals" are increasingly middle-class, conscious of their social and economic success, and looking for a spiritual style in keeping with a conception of life as a process and continuous unfolding of new insights.

A third spiritual journey is that of the "highly-active seeker," the most intense of all seeker types. These are people who explore one after another spirituality, some as serial seekers never finding what they are searching for, and almost all creating their own personal meaning system drawing selectively off the symbols, teachings, and practices at their disposal. When asked if they are "religious" or "spiritual" they are decidedly the latter and are often outright hostile to religious language and religious institutions. Religious language, many say, is fraught with oppressive teachings and preoccupied with power and control. Many have had negative experiences with the clergy or within a conservative congregation. A considerable number say that, because of divorce, their lifestyles, their views of the sacred, or whatever, they feel unwelcome in most churches. In speaking about God or the sacred, they are the most non-conventional: "Higher Power,"'cosmic consciousness," "realization of all human potential," and the like are terms freely expressed. They score the highest on survey indices of personal autonomy choosing to make their own decisions about moral and spiritual values, often believing in reincarnation and psychic powers, and holding that beliefs about God and the paranormal are a personal matter.

These highly-active spiritual seekers are of particular interest since they represent the most rootless, most questing of all the subgroups. Table shows the social correlates of these spiritual seekers. They appear to have been highly influenced by the post-sixties idealism and therapeutic culture with its emphasis upon self-fulfillment and potential for human growth. Many are well-educated, upscale professionals, yet considerable numbers report having had to scale down their expectations as they have grown older. Evidence of inconsistent statuses is apparent, which may help to explain their strong negative views toward religious institutions; bourgeois norms of respectability and conventionality are typically rejected. They tend to earn less income than others of their generation, are more likely to be separated or divorced, to hold liberal political views, and to have fewer conventional social networks of any kind. Judged on the basis of an index constructed from several indicators, 9 percent of our original survey population fit into this category. 
Table - Characteristics of Highly-Active Seekers

\begin{tabular}{|l|c|c|}
\hline & $\begin{array}{c}\text { Highly-Active Seekers } \\
(\mathrm{N}=50)\end{array}$ & $\begin{array}{c}\text { All Others } \\
(\mathrm{N}=486)\end{array}$ \\
\hline Over 35 years of age & $62 \%$ & $54 \%$ \\
Some College & 72 & 53 \\
White Collar & 67 & 60 \\
Professionals & 31 & 28 \\
Earns \$40,000+ annually & 37 & 45 \\
Married & 54 & 66 \\
Female & 54 & 50 \\
Liberal Political Views & 44 & 26 \\
No Religious Affiliation & 24 & 7 \\
\hline
\end{tabular}

Our recent survey shows them to have little regard for "brand" religions: they are more likely to leave behind the religion they grew up in and to select freely from a variety of traditions what to believe. Obligation and duty are not very important; what matters religiously is whether a particular belief or practice "helps one to grow." Almost twothirds say that because God is found within us, churches are not necessary. More so than do others, these highly-active seekers rely upon newsletters and the Internet in shaping their spiritual styles. Such resources buttress their individuality and view of spirituality as something people must take responsibility for largely themselves.

In many respects, they adhere to a style of "mystical religion" of the sort Ernst Troeltsch described many years ago when he spoke of attention to "direct, inward, and present religious experience" (1931: 730). Aside from being deeply personal, this mode of spirituality is polymorphic, open to continuing discovery and new insights from a variety of sources, yet monistic in seeing God, nature, science, and life unified in a single worldview. Monistic orientations emphasize that there is one and only oneultimate absolute essence, which is the true nature of all apparently separate beings and things. Because of the rejection of dualism and of literal, cognitive truth in favor of experiential truth, a mix of seemingly disparate religious and scientific ideas is not uncommon. Where these new-style mystics differ from Troeltsch's description is in their obvious lack of strong roots in any religious tradition: they are for the most part unscripted, adrift in a universe of evolving options. If the "pilgrim" is an image of the traditional Christian journey of faith, these seekers are more like Zygmunt Bauman's (1995: 95-98) postmodern "tourists," looking upon religions as places to visit, but seldom finding a metaphysical home they can claim as their own.

\section{III - New modes of religious production}

Generally, this interest in spirituality reflects the discontents of modernity: reactions to mind-body dualisms in Western culture; anti-responses to a rational, compartmentalized, and bureaucratized society; patriarchical religious structures; and loss of opportunity for the expression of the whole-self. Important, too, is the "shifting supply" of spiritual resources. In recent decades a new cadre of spiritual entrepreneurs have been successful at organizing and marketing spiritual themes across a broad spectrum, including astrology, guided meditation, channeling, shamanism, palmistry, numerology, and soulmaking; they have established bookstores, created Internet webpages, developed mail-order businesses, and installed 1-800 psychic lines. What is new is not the spiritual 
themes of course, but the technology and packaging that has helped to bring these themes into the middle-class mainstream and give them greater respectability. All these developments were possible by structural changes in American society over the past halfcentury.

The rise of the "spiritual" as a category of popular religious idiom cannot be understood apart from considerations of religious and cultural power. In times when religious establishments enjoy social prestige and cultural capital, and thus exercise monopolies, the term appears to languish. Actually not all that long ago - in the early sixties - the word "spiritual" was conspicuously absent in American public discourse; religious language and social ethics captured the day, making the word spirit' an almost forbidden word. But already at that time, social changes were underway that would, over the course of several decades, greatly transform the religious situation. Major legislation in 1965 rescinding immigration exclusion opened the doors to migrants with cultures and religions from around the world; shifts in policy by the Federal Communications Commission about the same time made it possible for televangelists to have easier access to television programming and to reach a larger public. Both of these developments were crucial in opening the way for new religious leaders, from the East especially, in the case of the first, and use of more advanced communication technology, in the case of the second. Combined the two represent a major step forward toward a more de-regulated religious market in the United States, turning the air waves into an arena for proselytizing and reshaping the dynamics of religious competition within the country (Finke and Iannaccone, 1993).

Cultural changes during this period were equally as significant: with the decline of an older Protestant consensus, there were subtle losses in power and control overreligious discourse. Aside from losses in religious membership and participation, there was the more significant loss of "religious capital" (Bourdieu, 1984) in the public arena. Religious control over symbolic frameworks underwent a considerable shift. Throughout late nineteenth century and up until about mid-twentieth century, religion exercised considerable control over spirituality through an expanded range of institutional structures such as camps, retreat centers, community centers, colleges, Bible schools, publishing houses, and hospitals. In this way organized religion exercised control and influence over a broad sector of life experiences. But this over-arching breadth began to diminish in the sixties and seventies. Non-religious alternatives to virtually all of these specialized organizations greatly expanded; religion's control over many spheres of life particularly health, education, and leisure - greatly diminished. By the late sixties, an increasingly more heterogeneous religious population combined with several decisive Supreme Court decisions meant that an older religious culture could no longer sustain its hold upon the public school and the public meeting place. So-called "alternative spiritualities" flourished in response to this loss of religious control. New Thought and the metaphysical traditions, long marginalized by the dominant religious influences, now enjoyed a revival of sorts. An alienated youth culture, higher levels of education, and the rise of the "knowledge class" all contributed to this metaphysical revival.

Consequently, the "spirituality industry" in America underwent massive changes in the years that followed. Bookstores, self-help groups, retreat centers, alternative medicine, spiritual seminars, workshops on spirituality in businesses and corporations, and now cyberspace as a medium for spiritual teachings, all emerged as new "outlets" for those seeking spiritual resources. In Pierre Bourdieu's words (1984), the "religious field" 
expanded to include a more varied set of agencies, each seeking to affirm its legitimacy and distinct claim upon spiritual resources. Competition in this broadened sense led to a restructuring of spiritual styles and practices, catering to the tastes and preferences of one after another distinct collectivity (for example, nature rituals associated with "ecospirituality,"'Motorcyclists for Jesus,"“channelling sessions"). With this increased elaboration of spiritual styles, individuals are challenged to examine and to think through which options might best serve their interests. All in all, what emerged was a more expanded, redefined religious market at the very time when many young people were becoming more self-reflexive about religious and spiritual matters. As often happens in American religion, with more varied supply came a higher total level of consumption.

Two types of "religious productions" have been particularly influential in shaping the spiritual marketplace. One is the rise of the so-called "seeker church." Often called "megachurches" because of their size, they are also known as full-service churches, seven-day-a-week churches, pastoral churches, new paradigm churches, shopping-mall churches. Rapidly growing in the mid- to late-nineties, these churches are attractive to the "unchurched," to the "superficially churched," and to those who for whatever reason dislike more traditional churches. Such churches are contrasted with the "believers' churches" since in much of their programming they deliberately attempt to reach those who are turned off by conventional religious language and/or unable to affirm belief. The goal is to make believers of them, but to start with, the programming is aimed at exploring religious questions and addressing their spiritual concerns, particularly their agnosticism, curiosity, and openness to exploring truth from many sources.

Such churches make skillful use of small groups for creating "a church of options," offering members a range of programs and ministries to select among, and thus catering to a culture stressing choice. Groups and fellowship opportunities are organized largely on the basis of personal experience and life-situations. The attempt at de-emphasizing conformity and offering a broad set of options allowing people to "create" their own spiritual styles and to find a niche where they can communicate and share with one another is quite deliberate. Visiting a megachurch, one recent commentator (Trueheart, 1996: 39) observed the following programmatic options:

....a seminar on effective single parenting; twelve-step recovery meetings by category (alcohol, drugs, abuse) and freeway coordinates; a parents-of-adolescents meeting; a class for premarital couples; another for "homebuildersr"; something called Bunko Night (Tired of shopping? Low on funds?"); a "woman in the workplace" brunch; a "fellowshippers" (seniors) meeting; a men's retreat ("Anchoring Deep"); women's Bible studies; a baseball league; a passel of Generation $\mathrm{X}$ activities; "grief support ministries"; worship music, drama, and dance; "discovering divorce dynamics"; a "belong class" for new members; and "life development" ("You will learn to know yourself and begin to see where God has a place of service for you. This is a can't miss class").

Seeker churches develop innovative forms of worship and make use of popular music, in an effort to convey a sense of authenticity and cultural adaptability. Above all, they try not to be boring. Sunday morning is defined as prime time for the "unchurched" seekers - little is expected of those attending, they may participate if they like but emphasis upon commitment and contribution is minimal. Overhead projectors, large screens, and sound systems making possible visual and audio connection with lyrics, cartoons, and Bible verses add to the overall experience. Drama and clips from film and television offer 
narratives about the dilemmas people face in everyday life. Meeting in auditoriums, if not in warehouses, where there are few religious symbols and no stained glasses plays down the "churchy" atmosphere and sends the message that people are welcome even if they know very little about the beliefs and practices of the tradition. The absence of a chancel gives the appearance that the sacred resides not in a place but in people's experiences. In sermons they hear about God, but it is a God that is less dogmatic and more tolerant of contemporary lifestyles than is the case for fundamentalists and other evangelicals. Strategies for building seeker churches are advanced through a fairly sizable network of leadership consultants, church growth experts, church-based training centers, and clergy who hold their own workshops. Non-denominational and community churches enjoy the advantage of not bringing with them the baggage often associated with historic denominations and of appealing more directly to experiential aspects of life. In one way or another, the public face of religion is profoundly altered to give it a more "user friendly" appearance; it becomes the religion of the people, rather than the perpetuation of an older and distant religious tradition.

40 A second major mode of "religious production" important in creating an eclectic spiritual market are the large-chain bookstores across the country with their expanded shelfspace devoted to spiritual topics. As one rather obvious indicator of this growth industry, the American Booksellers Association in 1995 opened for the first time at its convention and trade show a new and expanded section on "religious/spiritual/ inspirational" books. Here one observes new categories and vocabularies reinforced by the publishing industry: the old "religion" section is replaced by an expanding set of more specific rubrics, such as angels, Sufism, journey, recovery, mediation, Judaica,astrology, gurus, prophesy, Buddhism, channeling, esoterica, and the like. A more differentiated range of topics caters to the possibility that spiritual wisdom may be discovered not just through awareness of the varied sources, but by in-depth exploration of specific topics. Obviously this amounts to a major marketing strategy "selling" spirituality in its many styles to a national audience. The fact that many religious publishers have been bought out by large secular presses indicates not just a shift in control over religious production, but also points to the power of the industry in defining and standardizing the spiritual marketplace.

41 The content of the popular books deserves consideration, since themes that surface here are closely associated with those we discovered in our surveys with young Americans. "Demand" and "supply" are linked in complex and mutually interlocking ways.

Based upon book sales, four categories of religious books top the sales charts. Most popular are books on near-death experiences, angels, the invasion of aliens-all catering to an audience caught, as Phyllis Tickle (1995: 39) says, "somewhere between belief in and curiosity about such possibilities." Not very surprisingly, the quest for the supernatural flourishes in such a context. Curiosity about extra-terrestrial beings has mushroomed in recent years. A Harris poll in 1997 reports that almost 60 percent of Americans believe that there is some kind of sensible being out there in space, a belief more common among the more highly educated. The fact that such belief is so widespread among educated Americans signals a significant shift in popular spirituality.

43 Next are books on ancient wisdom which generally assume that something terribly important to human life has been lost in the modern world but hopefully can be regained. Buddhism, Native American spiritual experiences, neo-paganism, Wicca, feminist insights, and assorted New Age teachings all fall under this rubric, and all in one way or 
another promising greater fullness to life. Here we see something of the frantic quest to find full exposure to spiritual possibilities in times past and concerted efforts, as Danièle Hervieu-Léger (1995) has noted, to create "imaginary genealogies" placing the seeker in some line of religious descent. In so doing, the book industry is quite successful in posturing to the rootlessness and uncertainty of the current generations.

Third are self-help books pitched to the well-being of the practitioner and the use of spiritual disciplines for gaining power and control over whatever ills beset people. Technique is privileged here as the means for therapeutic exploration and as a way of dealing with life's dilemmas. There is a strong emphasis upon rationality and instrumentality - the "how to" manual now pitched to just about every conceivable addiction or compulsion from overeating to gambling or drugs, to working too hard, to not succeeding in love and relationships. Even fundamentalist Christianity is viewed as an addiction for some people, and thus something people can "work on" if they want out of it. Recovery as a theme appeals to a sizable proportion of the society seeking to improve their lives.

Finally, there is religious fiction, a rapidly-expanding genre with labels for just about every imaginable constituency or interest. As Phyllis Tickle (1995: 48) writes: "Call it religious fiction or inspirational fiction or by any of its sectarian names of Jewish, Catholic, Christian, or Evangelical. Or call it by some combination of them, like religious mysteries, Jewish historical novels, Evangelical Christian westerns,inspirational romances, and so on." The permutations seem endless, allowing the book market to exploit the fluid, exploratory spiritual context at present. Whatever else this proliferating book market may imply, it signals a degree of restiveness and insecurity in the culture, and also, the success of a new cadre of entrepreneurs at targeting particular niches of life-experience and endowing them with sacred significance.

Both types of religious production examined here - seeker churches and the book industry - overlap to some extent. Publishing firms supply books, videos, and audio cassettes used in seeker churches; likewise, seeker churches address concerns that often get dealt with in commercial publications and related media. Other influences perpetuate a spiritual quest culture as well: recent television programming with shows about angels, aliens, and priest struggling with faith and doubt; spiritual seminars organized around topical themes; and of course the Internet with its information, chat rooms, and cyber chapels allowing people to relate virtually, if not face-to-face, around concerns of their choice. Increasingly in a religious and cultural context as this, the institutional boundaries sustaining spirituality are porous. "No single institution," as Nancy Ammerman (1997: 206) says, "absorbs our religious energies either over a lifetime or at any given moment."

\section{IV - Conclusion}

What about the future? For sure, the spiritual trends now underway will extend into the next century and continue re-shaping the religious landscape. One scenario would be a growing polarization as New Age spiritualities and fundamentalist Christianity contend with one another. Among religious leaders there is a good deal of hostility and tension at present; for most Americans, however, the battle lines are not so clearly drawn. Despite predictions of a "culture war," there are strong forces within American society that push in the direction of tolerance and moderation. Hence another scenario would suggest a 
mutual recognition of religious extremes and some degree of harmonization of symbols and teachings at the grass-roots level, in keeping with the observation that seeker motifs are widely distributed across religious communities and the country as a whole. The very fact that the fuss raised over Hillary Rodham Clinton's exploration of guided meditations and imaginary conversations was so short-lived may be a sign of what we can expect in the future: an ever more pluralistic, multi-layered religious and spiritual scene bound not by unity of belief but by civic norms of tolerance and openness to believers and nonbelievers of various kinds. At the very least, we can expect a society in which spiritual concerns are widely dispersed, inside and outside religious organizations, and individuals taking an active, and often largely independent, role in cultivating their own inner lives. Churches, synagogues, and temples will continue to adapt to a quest culture, and the spiritual marketplace should continue to flourish into the foreseeable future.

\section{BIBLIOGRAPHY}

AMMERMAN Nancy T., “Organized Religion in a Voluntaristic Society”Sociology of Religion, 58, 1997,pp. 203-215.

BAINBRIDGE William Sims, The Sociology of Religious Movements, New York, Routledge, 1997.

BAUMAn Zygmunt, Life in Fragments: Essays in Postmodern Morality, Oxford, Blackwell, 1995.

BOURDIEU Pierre, Distinction: A Social Critique of the Judgment of Taste, Cambridge, Harvard UniversityPress, 1984.

FINKE Roger, IANNACCONE Laurence R., "Supply-Side Explanations for Religious Change”, The Annals of theAmerican Academy of Political and Social Science, 527, May 1993, pp. 27-39.

GIDDINGS Anthony, The Consequences of Modernity, Stanford, Stanford University Press, 1990.

HERVIEU-LÉGER Danièle, “Modernity, Secularization, and Religious Memory in Western Europe”, unpublished paper, 1995.

INGLEHART Ronald, Culture Shift in Advanced Industrial Society, Princeton, Princeton University Press, 1990.

JAMES William, The Varieties of Religious Experience, New York, Vintage Books, 1990.

LIFTON Robert Jay, The Protean Self: Human Resilience in an Age of Fragmentation, New York, Basic Books, 1993.

MILLER Donald E., Reinventing American Protestantism: Christianity in the New Millenium, Berkeley,University of California Press, 1997.

REDFIELD James, “The Celestine Journal”, vol. 3, September 1996.

Roof Wade Clark, A Generation of Seekers, San Francisco, Harper San Francisco, 1993.

Roof Wade Clark, CARroll Jackson W., ROOZEN David A., The Post-War Generation and Establishment Religion:Cross-Cultural Perspectives. Boulder, Westview Press, 1995. 
SHEEHY Gail, New Passages:Mapping Your Life Across Time, New York, Random House, 1995.

SHIBLEy Marc A., Resurgent Evangelicalism in the United States, Columbia, University of South CarolinaPress, 1996.

STEINFELS Peter, Santa Barbara News-Press, July 27, 1996.

TICKLE Phyllis A., Re-Discovering the Sacred, New York, Crossroad Publishing Company, 1995.

TROELTSCH Ernst, The Social Teachings of the Christian Churches, London, George Allen and Unwin, 1931.

TRUEHEART Charles, "Welcome to the Next Church", The Atlantic Monthly, August 1996.

\section{ABSTRACTS}

This paper examines the rise of a spiritual quest culture in the United States. A large-scale survey of the post-World War II baby-boom generation reveals high levels of fluidity, of people moving in and out of religious groups and of frequent changes in beliefs and practices. The term "spiritual" is now commonly used to identify oneself, usually conjoined with the word "religious" but often not. Spiritual concerns are widely expressed, having to do especially with "journey" and "recovery" mong groups as diverse as evangelical Christians and more open-minded metaphysical believers. This changing style of spirituality is described as "reflexive," with its emphasis on self-engagement, exploration, and process. Discussed are the new modes of religious production which make use of the "spiritual" as a category, particularly the rise of the "seeker church" and an expanded religious book market with its appeals to those searching for answers.

L'article analyse l'émergence d'une culture de la quête religieuse aux États-Unis. Une vaste enquête auprès de la génération du baby-boom de l'après-guerre révèle une grande fluidité ainsi qu'une intense circulation des gens d'un groupe religieux à l'autre et des changements fréquents en termes de croyances et de pratiques. Les acteurs utilisent souvent le mot «spirituel » pour se définir, auquel ils associent parfois, mais pas le plus souvent, celui de «religieux». Les préoccupations spirituelles, liées à des notions telles que le "voyage » et la " guérison ", sont fréquemment évoquées tant parmi les chrétiens évangéliques que chez des groupes à l'esprit plus ouvert nourrissant eux aussi des croyances métaphysiques. Ce nouveau type de spiritualité est décrit comme "réflexif", il accorde une large importance à l'engagement personnel, à l'exploration, à l'idée de processus. L'auteur analyse les nouveaux modes de production religieuse qui usent du «spirituel » comme catégorie, en particulier la montée de l'Église des « seekers » et l'expansion d'un marché du livre religieux particulièrement attractif pour ceux qui cherchent des réponses.

El articulo analiza la conformación de una cultura de búsqueda religiosa en los Estados Unidos. Una encuesta amplia entre la generación del baby-boom de la época de posguerra pone de manifiesto una fluidez importante, así como una circulacion intensa de los individuos de un grupo religioso a otro, y cambios frecuentes en terminas de creencias y de prácticas. Los adores utilizan frecuentemente la palabra 'espiritual' para definirse, y solamente en algunas ocasiones la asocian a la palabra 'religioso'. Las preocupaciones espirituales, relacionadas con nociones como el 'viaje' o la 'cura-ciàn', son frecuentemente evocadas por los individuos, tanto entre los cristianos evan-gélicos como entre grupos más abiertos que también abrigan creencias metafísicas. El autor describe este nuevo tipo de espiritualidad como 'reflexivo', dando una importancia central al compromiso personal, a la exploración, y a la idea de proceso. El autor analiza también los nuevos modos de producción religiosa, que usan lo 'espiritual' como 
categoria, interesándose más precisamente en el caso del auge de la Iglesia de los 'seekers', asi como en el desarrollo de un mercado del libro religioso que es particular-mente atractivo para todos los que buscan respuestas.

\section{AUTHOR}

\section{WADE CLARK ROOF}

University of California Santa Barbara 